\title{
Industrial coke as an electrode material for environmental remediation
}

\section{Supplementary Material}

\author{
Jamie Haner, Keegan Rankin, Dorin Bejan, and Nigel J. Bunce* \\ Electrochemical Technology Centre \\ Chemistry Department, University of Guelph \\ Guelph, Ontario, Canada N1G 2W1
}

\begin{abstract}
Industrial coke was evaluated as a low-cost electrode material for environmental remediation, using the dye, Orange II, as an example substrate. Coke was used as massive pieces batch cells, or in the ground form for use in a packed bed reactor. The loss of Orange II was faster when the supporting electrolyte contained chloride ion, and under these conditions the reaction involved hypochlorination. In the batch reactor the current efficiency for mineralization was only modest (4-14\%). In the packed bed reactor, the loss of both starting material and intermediates was fastest at high current and low flow rate, and a near-quantitative current efficiency was achieved. The high current efficiency was explained by the greater surface area of the electrodes in the packed bed reactor compared with the batch reactor, and better contact between the solution to be remediated and the coke particles. A drawback to the use of coke electrodes for the remediation of aqueous wastes is their tendency to increase the Total Organic Carbon content of an aqueous solution, especially under anodic polarization.
\end{abstract}

* Address correspondence to N.J. Bunce: e-mail nbunce@uoguelph.ca; telephone 1-519824-4120 Extension 53962 
Table S1: TOC results for $0.06 \mathrm{M} \mathrm{Na}_{2} \mathrm{SO}_{4}$ and $0.1 \mathrm{M} \mathrm{KCl}$, electrolyzed at $25 \mathrm{~mA}$ in the absence of Orange II with coke and graphite electrodes in the divided and undivided cell.

\begin{tabular}{|c|c|c|c|c|}
\hline Electrolyte & Compartment & Time (min) & Electrodes & TOC (mg/L) \\
\hline $0.1 \mathrm{M} \mathrm{KCl}$ & - & 0 & - & 0.9 \\
\hline $0.1 \mathrm{M} \mathrm{KCl}$ & Anodic & 12.5 & Coke & 6.5 \\
\hline $0.1 \mathrm{M} \mathrm{KCl}$ & Cathodic & 12.5 & Coke & 7.1 \\
\hline $0.06 \mathrm{M} \mathrm{Na}_{2} \mathrm{SO}_{4}$ & - & 0 & - & 1.1 \\
\hline $0.06 \mathrm{M} \mathrm{Na}_{2} \mathrm{SO}_{4}$ & Anodic & 40 & Coke & 7.8 \\
\hline $0.06 \mathrm{M} \mathrm{Na}_{2} \mathrm{SO}_{4}$ & Cathodic & 40 & Coke & 8.9 \\
\hline $0.1 \mathrm{M} \mathrm{KCl}^{2} \mathrm{M} \mathrm{KCl}_{0.1}$ & Anodic & 30 & Graphite & 1.7 \\
\hline $0.1 \mathrm{M} \mathrm{KCl}$ & Cathodic & 30 & Graphite & 2.7 \\
\hline $0.06 \mathrm{M} \mathrm{Na}_{2} \mathrm{SO}_{4}$ & - & 0 & - & 2.3 \\
\hline $0.06 \mathrm{M} \mathrm{Na}_{2} \mathrm{SO}_{4}$ & Anodic & 40 & Graphite & 7.4 \\
\hline $0.06 \mathrm{M} \mathrm{Na}_{2} \mathrm{SO}_{4}$ & Cathodic & 40 & Graphite & 2.5 \\
\hline
\end{tabular}


Table S2: First order rate data as a function of current in the electrolysis of $0.1 \mathrm{mM}$ Orange II in the undivided batch reactor

\begin{tabular}{|c|c|c|c|}
\hline Current $(\mathrm{mA})$ & Rate Constant $\left(\mathrm{min}^{-1}\right)$ & $\mathrm{R}^{2}$ & Cell Voltage (V) \\
\hline 100 & 0.070 & 0.973 & $\sim 4.2$ \\
\hline 50 & 0.067 & 0.993 & $\sim 3.6$ \\
\hline 25 & 0.056 & 0.988 & $\sim 3.1$ \\
\hline 5 & 0.054 & 0.970 & $\sim 2.9$ \\
\hline 2 & 0.035 & 0.912 & $\sim 2.1$ \\
\hline 1 & 0.030 & 0.960 & $\sim 1.6$ \\
\hline
\end{tabular}


Table S3: Electrolysis of $0.1 \mathrm{mM}$ Orange II in $0.1 \mathrm{M} \mathrm{KCl}$ or $0.06 \mathrm{M} \mathrm{Na}_{2} \mathrm{SO}_{4}$ at $25 \mathrm{~mA}$ for $120 \mathrm{~min}$.

\begin{tabular}{|l|l|l|l|l|l|}
\hline $\begin{array}{l}\text { Supporting } \\
\text { Electrolyte }\end{array}$ & System & $\begin{array}{l}\text { TOC } \\
(\mathrm{mg} / \mathrm{L})\end{array}$ & $\begin{array}{l}\text { Percent } \\
\text { Mineralized }\end{array}$ & $\begin{array}{l}\text { Solution } \\
\text { Volume, } \\
\mathrm{mL}\end{array}$ & $\begin{array}{l}\text { \% Current } \\
\text { Efficiency }\end{array}$ \\
\hline $\mathrm{Na}_{2} \mathrm{SO}_{4}$ & Anodic Compartment & 22.9 & 21 & 40 & 4 \\
\hline $\mathrm{KCl}$ & Anodic Compartment & 27.6 & N/A & 40 & N/A \\
\hline $\mathrm{Na}_{2} \mathrm{SO}_{4}$ & $\begin{array}{l}\text { Cathodic } \\
\text { Compartment }\end{array}$ & 20.9 & 37 & 35 & 6 \\
\hline $\mathrm{KCl}$ & $\begin{array}{l}\text { Cathodic } \\
\text { Compartment }\end{array}$ & 17.5 & 47 & 35 & 7 \\
\hline $\mathrm{Na} 2 \mathrm{SO}_{4}$ & Undivided Cell & 23.1 & 21 & 75 & 7 \\
\hline $\mathrm{KCl}$ & Undivided Cell & 18.1 & 42 & 75 & 14 \\
\hline
\end{tabular}

Comments: These experiments were carried out in the $75 \mathrm{~mL}$ batch cell, of which the anodic compartment had volume $40 \mathrm{~mL}$ and the cathodic compartment ahd volume 35 $\mathrm{mL}$. The initial TOC (calculated) for $0.1 \mathrm{mM}$ Orange II is $19.2 \mathrm{mg} / \mathrm{L}$, to which must be added TOC due to the dionized water $(1 \mathrm{mg} / \mathrm{L})$ and TOC released from the coke electrodes upon electrolysis (1-6 mg/L: see main text). We cannot use the rate constant for loss of Orange II to calculate the \% current efficiency, because the rate of loss of Orange II is much greater than the rate of loss of TOC. The lack of precision of the date is illustrated by Entry \#2 of the Table, which showed zero apparent loss of TOC after correction for TOC deposited into the solution from the electrodes. 
Table S4: TOC Blanks (at steady state) of electrolyzed and non-electrolyzed solutions of $0.1 \mathrm{M} \mathrm{KCl}$ with granular coke electrodes in a flow reactor with a flow rate of $1 \mathrm{~mL} / \mathrm{min}$.

\begin{tabular}{|l|l|l|c|}
\hline Current & $\begin{array}{l}\text { Electrode } \\
\text { Configuration }\end{array}$ & Sample Taken & TOC (mg/L) \\
\hline 0 & NA & Gap & 19 \\
\hline 0 & NA & Outlet & 16 \\
\hline 200 & AC & Gap & 51 \\
\hline 200 & AC & Outlet & 33 \\
\hline 200 & CA & Gap & 34 \\
\hline 200 & CA & Outlet & \\
\hline
\end{tabular}


Table S5: TOC of treated samples of Orange II in $0.1 \mathrm{M} \mathrm{KCl}$ or $0.06 \mathrm{M} \mathrm{Na}_{2} \mathrm{SO}_{4}$

discharged from the packed bed reactor at $200 \mathrm{~mA}$ at various flow rates in both the anode to cathode and cathode to anode electrode configurations.

\begin{tabular}{|l|l|l|l|}
\hline $\begin{array}{l}\text { Flow Rate } \\
(\mathrm{mL} / \mathrm{min})\end{array}$ & $\begin{array}{l}\text { Reactor } \\
\text { Configuration }\end{array}$ & $\begin{array}{l}\text { Supporting } \\
\text { Electrolyte }\end{array}$ & TOC $(\mathrm{mg} / \mathrm{L})$ \\
\hline 1 & AC & $\mathrm{Na}_{2} \mathrm{SO}_{4}$ & 27 \\
\hline 1 & CA & $\mathrm{Na}_{2} \mathrm{SO}_{4}$ & 55 \\
\hline 1 & AC & $\mathrm{KCl}$ & 27 \\
\hline 1 & CA & $\mathrm{KCl}$ & 56 \\
\hline 2.5 & AC & $\mathrm{Na}_{2} \mathrm{SO}_{4}$ & 23 \\
\hline 2.5 & CA & $\mathrm{Na}_{2} \mathrm{SO}_{4}$ & 36 \\
\hline 2.5 & AC & $\mathrm{KCl}$ & 22 \\
\hline 2.5 & CA & $\mathrm{KCl}_{37}$ \\
\hline 4 & AC & $\mathrm{Na}_{2} \mathrm{SO}_{4}$ & 28 \\
\hline 4 & CA & $\mathrm{Na}_{2} \mathrm{SO}_{4}$ & 39 \\
\hline 4 & AC & $\mathrm{KCl}$ & 24 \\
\hline 4 & CA & $\mathrm{KCl}$ & 41 \\
\hline
\end{tabular}


Table S6: TOC results for solutions of $0.11 \mathrm{mM}$ sulfanilic acid electrolysed with coke electrodes at $25 \mathrm{~mA}$ in the presence of $0.1 \mathrm{M} \mathrm{KCl}$ or $0.06 \mathrm{M} \mathrm{Na}_{2} \mathrm{SO}_{4}$ in a $40 \mathrm{~mL}$ batch cell, or $40 \mathrm{~mL}$ anodic compartment of a divided cell.

\begin{tabular}{|c|c|c|c|c|c|}
\hline System & $\begin{array}{l}\text { Experimental } \\
\text { TOC (mg/L) }\end{array}$ & $\begin{array}{l}\text { Blank } \\
(\mathrm{mg} / \mathrm{L})\end{array}$ & $\begin{array}{c}\text { Expected TOC } \\
\text { (Blank + } \\
\text { Unelectrolyzed) }\end{array}$ & $\begin{array}{c}\text { TOC } \\
\text { Mineralized } \\
\text { (Expected - } \\
\text { Experimental) }\end{array}$ & $\begin{array}{c}\text { Percent } \\
\text { Mineralized }\end{array}$ \\
\hline $\begin{array}{l}0.1 \mathrm{M} \mathrm{KCl} \text {, no } \\
\text { electrolysis }\end{array}$ & 7.9 & -- & 7.9 & -- & -- \\
\hline $\begin{array}{l}0.1 \mathrm{M} \mathrm{KCl} \\
\text { electrolysed for } \\
12.5 \mathrm{~min}, \\
\text { undivided }\end{array}$ & 11.3 & 6.5 & 14.4 & 3.1 & 39 \\
\hline $\begin{array}{l}0.1 \mathrm{M} \mathrm{KCl} \\
\text { electrolysed for } \\
12.5 \text { min, anodic } \\
\text { compartment }\end{array}$ & 11.0 & 7.1 & 15.0 & 3.1 & 39 \\
\hline $\begin{array}{l}0.06 \mathrm{M} \mathrm{Na}_{2} \mathrm{SO}_{4} \text {, } \\
\text { no electrolysis }\end{array}$ & 7.7 & -- & 7.7 & -- & -- \\
\hline $\begin{array}{l}0.06 \mathrm{M} \mathrm{Na}_{2} \mathrm{SO}_{4}, \\
\text { electrolysed for } 40 \\
\text { min, undivided }\end{array}$ & 13.7 & 8.8 & 16.5 & 2.8 & 37 \\
\hline $\begin{array}{l}0.06 \mathrm{M} \mathrm{Na}_{2} \mathrm{SO}_{4}, \\
\text { electrolysed for } 40 \\
\text { min, anodic } \\
\text { compartment }\end{array}$ & 15.5 & 7.8 & 15.5 & 0.0 & 0 \\
\hline
\end{tabular}

Comment: The last entry, which suggests zero mineralization reflects the general problem that the TOC mineralized is the difference, often a small difference, between the electrolyzed and the unelectrolyzed solutions. Consequently, we believe that all the TOC results should be considered as semi-quantitative at best. 


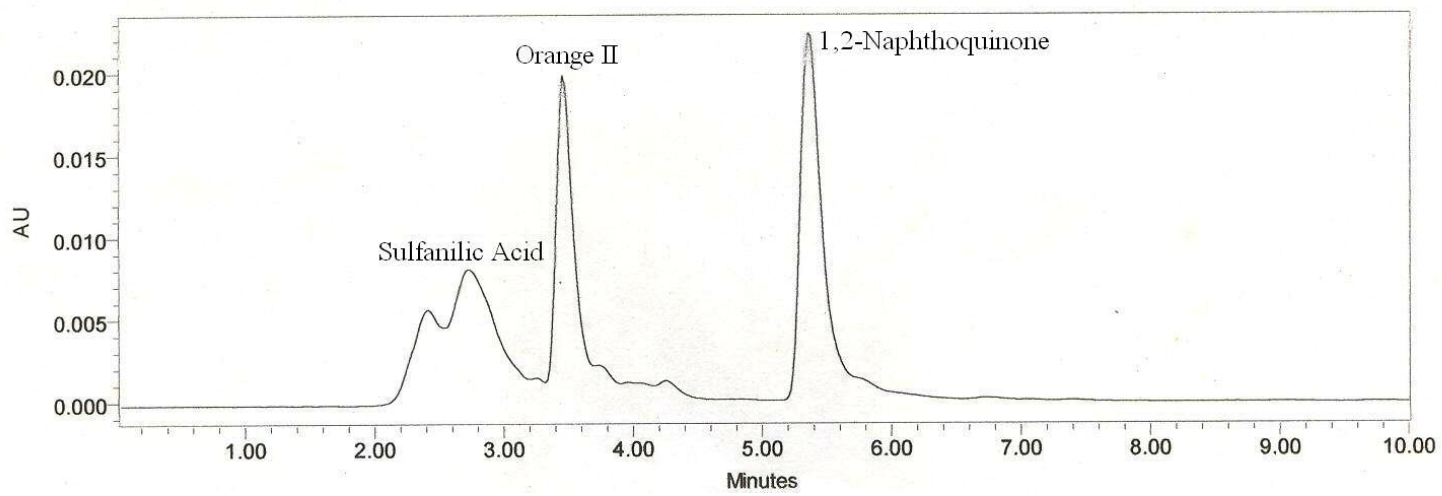

Figure S1: Sample chromatogram of $75 \mathrm{~mL} 0.1 \mathrm{mM}$ Orange II in $0.1 \mathrm{M} \mathrm{KCl}$ electrolyzed with coke electrodes at $25 \mathrm{~mA}$ for 45 minutes. 


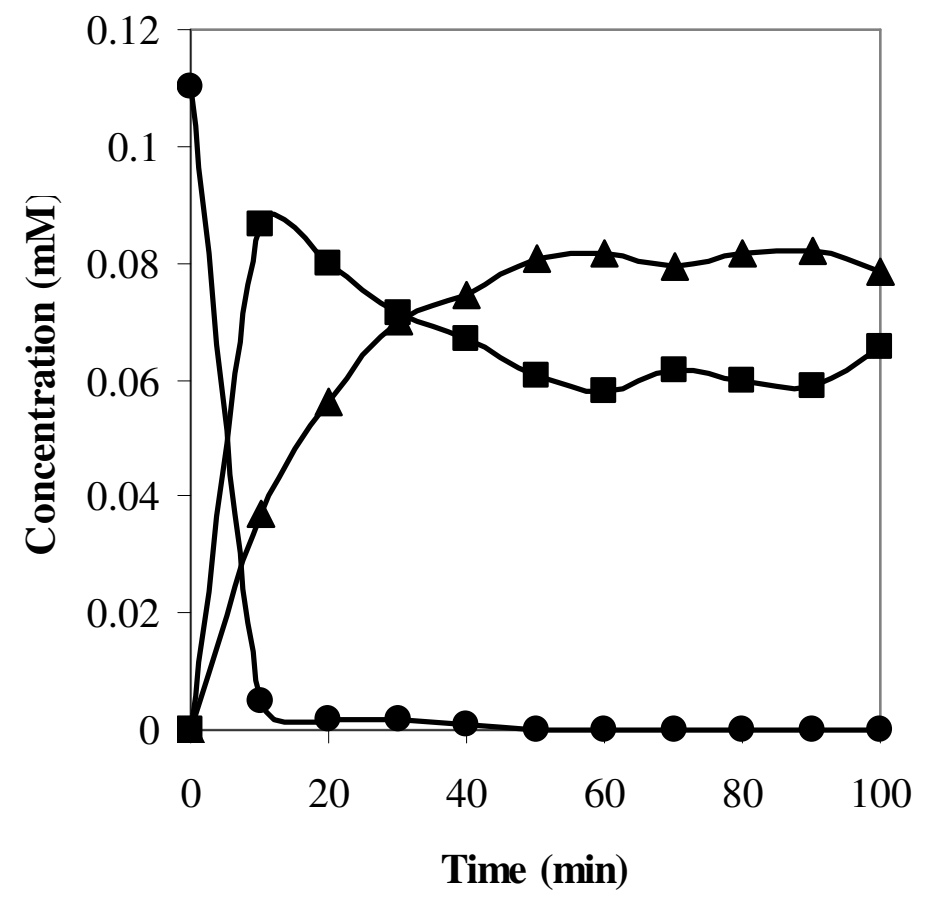

Figure S2: Electrolysis of $0.1 \mathrm{mM}$ Orange II with $0.06 \mathrm{M}$ sodium sulfate supporting electrolyte in a packed bed reactor (configuration CA) at a current of $25 \mathrm{~mA}$ and a flow rate of $5 \mathrm{~mL} / \mathrm{min}$. $\bullet$ - Orange II; $\boldsymbol{\Delta}$ - sulfanilic acid; $\boldsymbol{\bullet}$ - 1,2-naphthoquinone. 


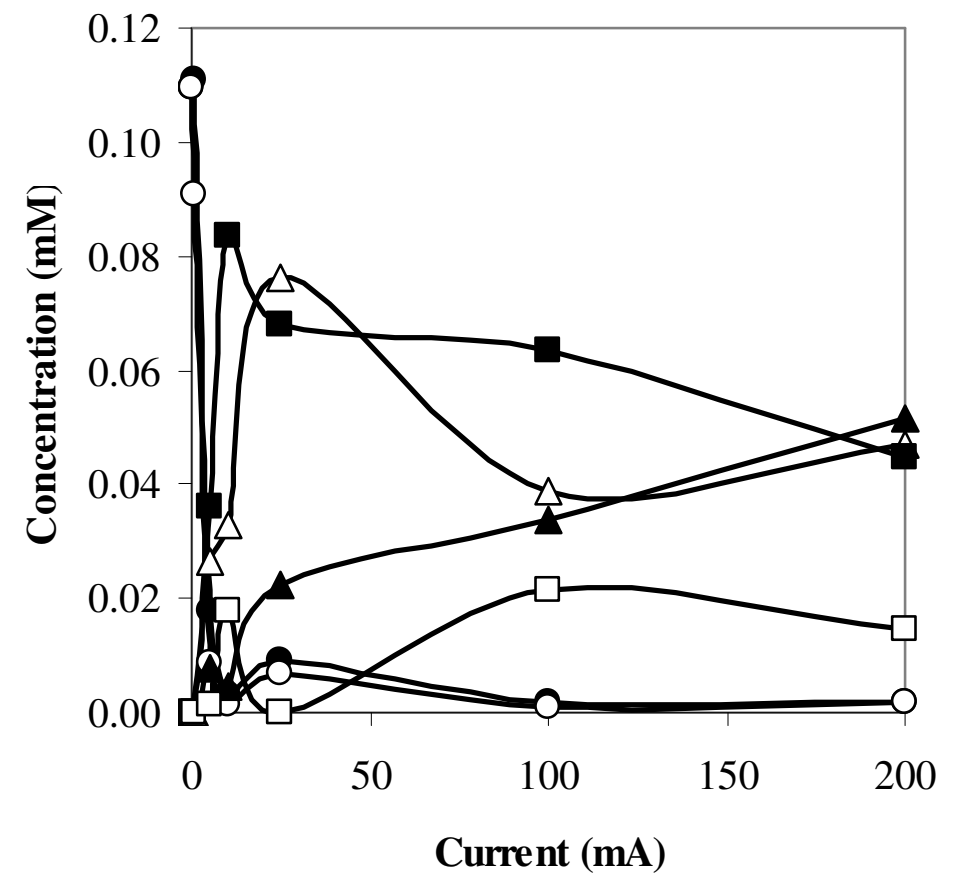

Figure S3: Concentration of Orange II and its electrolysis products in $0.06 \mathrm{M} \mathrm{Na}_{2} \mathrm{SO}_{4}$ using the flow-through packed bed reactor in Configuration $\mathrm{AC}$ with flow rate of $2.5 \mathrm{~mL}$ $\min ^{-1}$ and various currents. $\bullet$ - Orange II gap; $\bigcirc$ - Orange II outlet; $\boldsymbol{\Delta}$ - Sulfanilic acid gap; $\Delta$ - Sulfanilic acid outlet; $\boldsymbol{\square}$ - 1,2-naphthoquinone gap; $\square$ - 1,2-naphthoquinone outlet. 


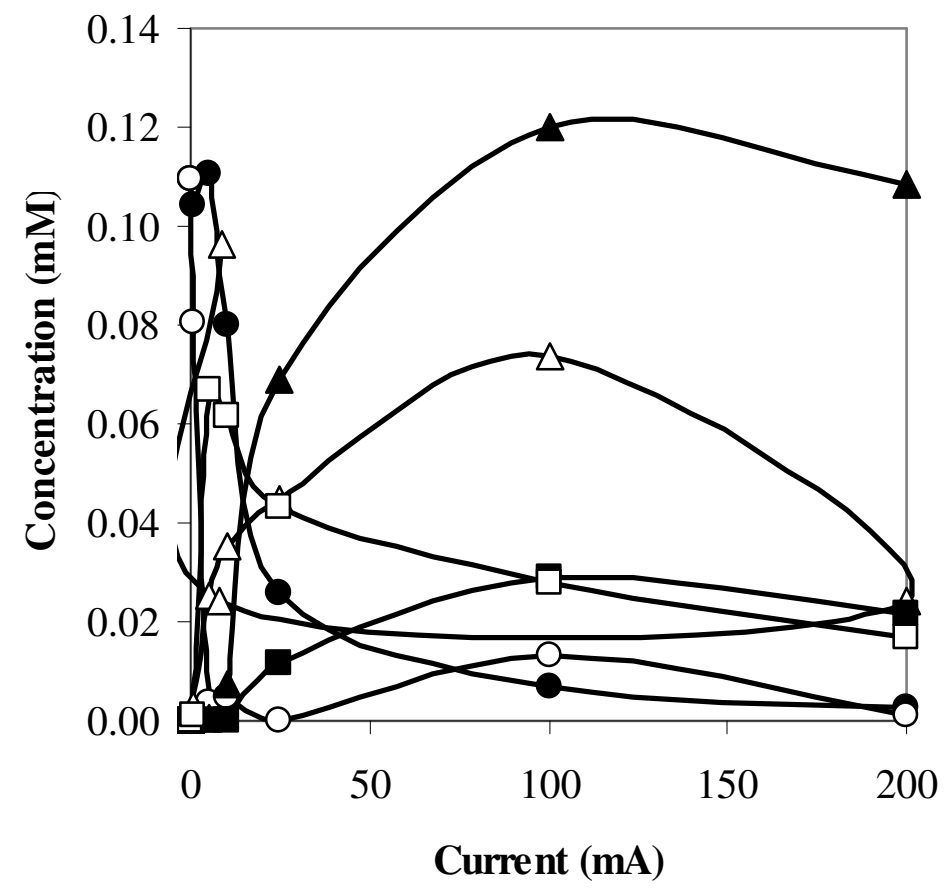

Figure S4: Concentration of Orange II and its electrolysis products in $0.06 \mathrm{M} \mathrm{Na}_{2} \mathrm{SO}_{4}$ using the flow-through packed bed reactor in Configuration CA with flow rate of $2.5 \mathrm{~mL}$ $\min ^{-1}$ and various currents. $\bullet$ - Orange II gap; ○ - Orange II outlet; $\boldsymbol{\Delta}$ - Sulfanilic acid gap; $\Delta$ - Sulfanilic acid outlet; $\mathbf{\square}$ - 1,2-naphthoquinone gap; $\square$ - 1,2-naphthoquinone outlet. 


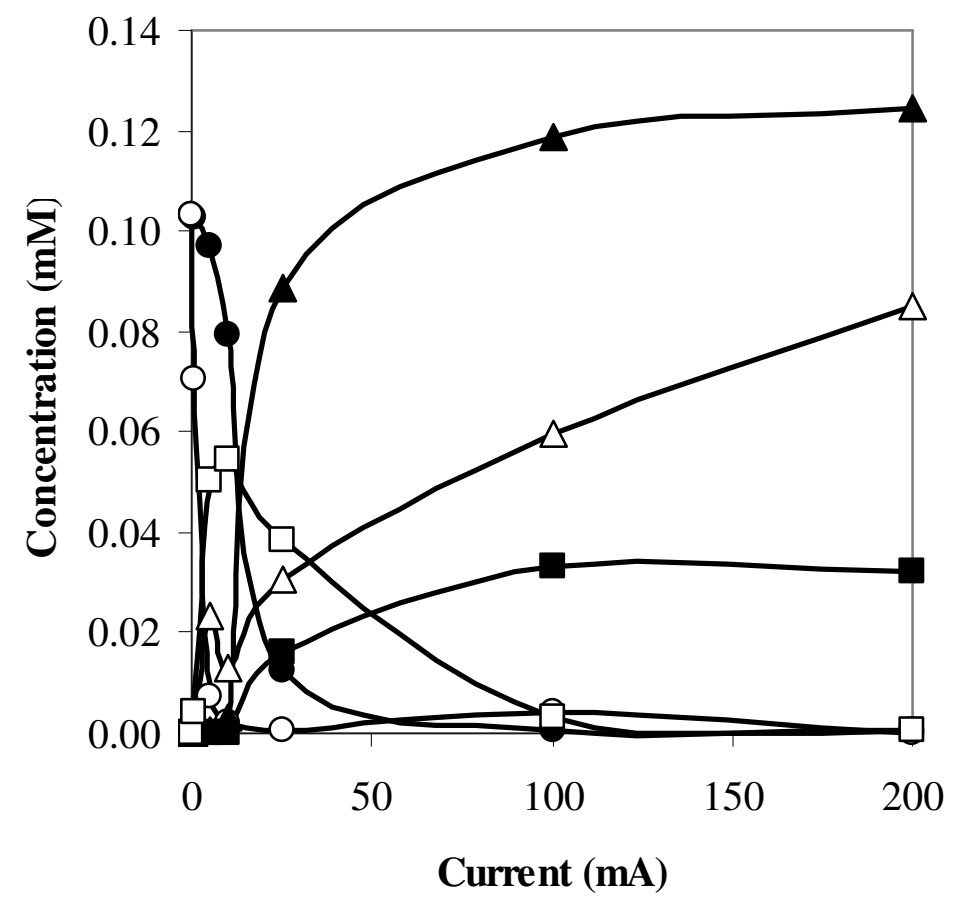

Figure S5: Concentration of Orange II and its electrolysis products in $0.1 \mathrm{M} \mathrm{KCl} \mathrm{using}$ the flow-through packed bed reactor in Configuration CA with flow rate of $2.5 \mathrm{~mL} \mathrm{~min}^{-1}$ and various currents. $\bullet$ - Orange II gap; $\bigcirc$ - Orange II outlet; $\boldsymbol{\Lambda}$ - Sulfanilic acid gap; $\Delta$ - Sulfanilic acid outlet; $\mathbf{\square}$ - 1,2-naphthoquinone gap; $\square$ - 1,2-naphthoquinone outlet. 


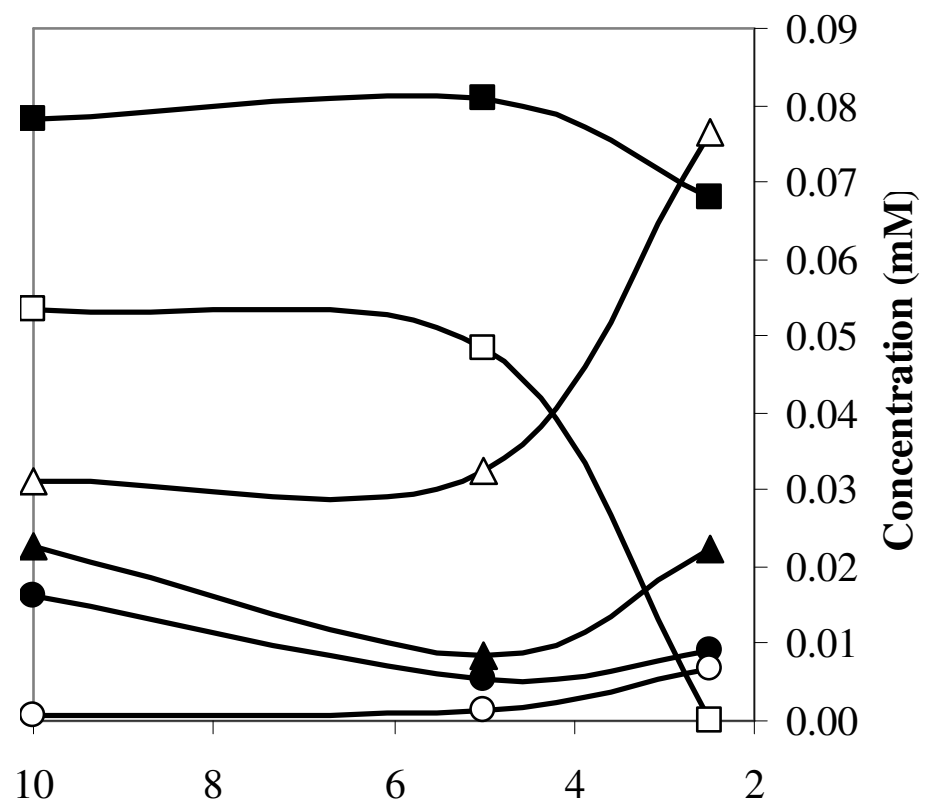

Flow Rate (mL/min)

Figure S6: Concentration of Orange II and its electrolysis products in $0.06 \mathrm{M} \mathrm{Na}_{2} \mathrm{SO}_{4}$ using the flow-through packed bed reactor in Configuration $\mathrm{AC}$ with current $25 \mathrm{~mA}$ and various flow rates. $\bullet$ - Orange II gap; $\bigcirc$ - Orange II outlet; $\boldsymbol{\Delta}$ - Sulfanilic acid gap; $\Delta$ Sulfanilic acid outlet; $\mathbf{\square}$ - 1,2-naphthoquinone gap; $\square$ - 1,2-naphthoquinone outlet. 


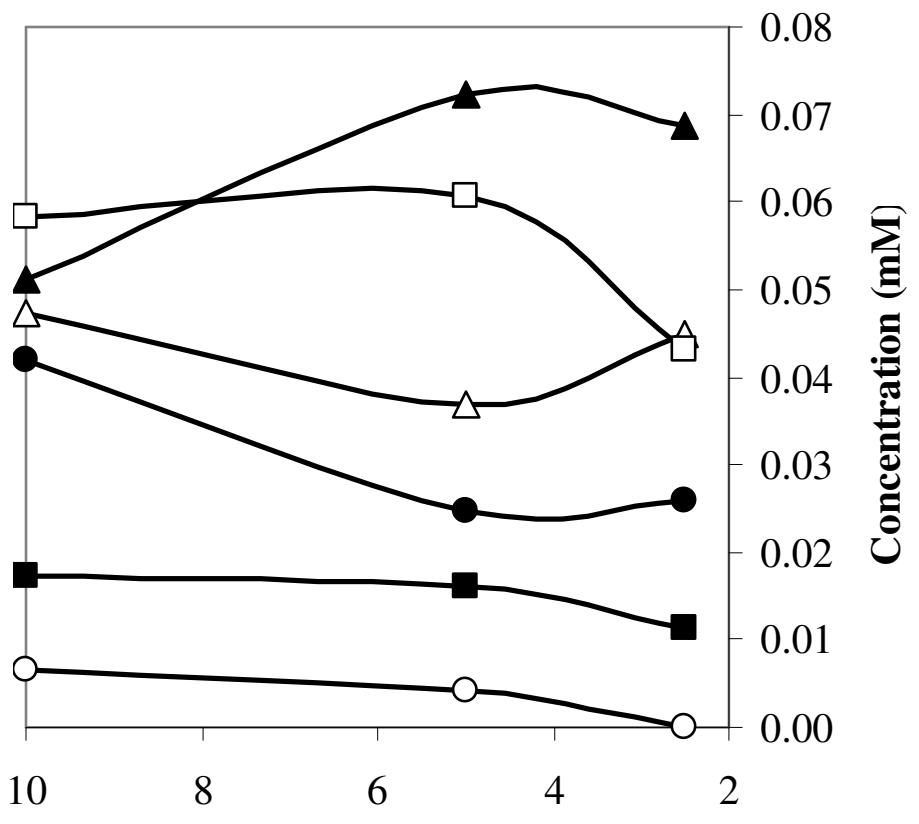

Flow Rate (mL/min)

Figure S7: Concentration of Orange II and its electrolysis products in $0.06 \mathrm{M} \mathrm{Na}_{2} \mathrm{SO}_{4}$ using the flow-through packed bed reactor in Configuration CA with current $25 \mathrm{~mA}$ and various flow rates. $\bullet$ - Orange II gap; $\bigcirc$ - Orange II outlet; $\boldsymbol{\Delta}$ - Sulfanilic acid gap; $\Delta$ Sulfanilic acid outlet; $\mathbf{\square}$ - 1,2-naphthoquinone gap; $\square$ - 1,2-naphthoquinone outlet. 


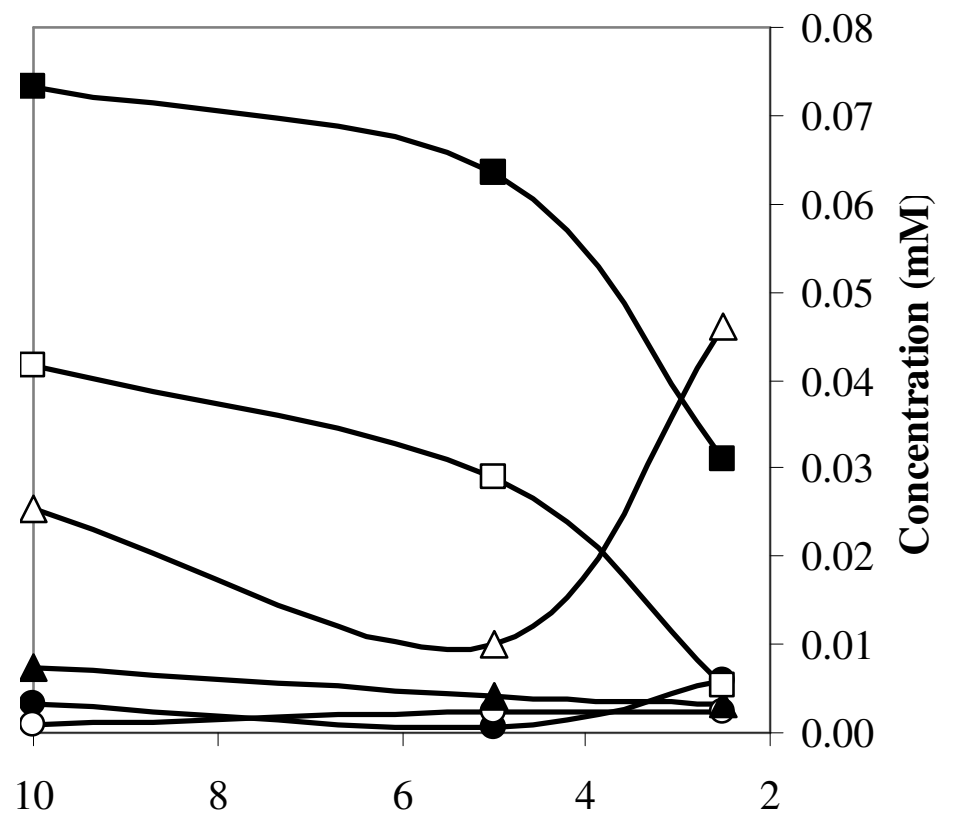

Flow Rate (mL/min)

Figure S8: Concentration of Orange II and its electrolysis products in $0.1 \mathrm{M} \mathrm{KCl}$ using the flow-through packed bed reactor in Configuration $\mathrm{AC}$ with current $25 \mathrm{~mA}$ and various flow rates. $\bullet$ - Orange II gap; $\bigcirc$ - Orange II outlet; $\boldsymbol{\Delta}$ - Sulfanilic acid gap; $\Delta$ Sulfanilic acid outlet; $\mathbf{\square}$ - 1,2-naphthoquinone gap; $\square$ - 1,2-naphthoquinone outlet. 


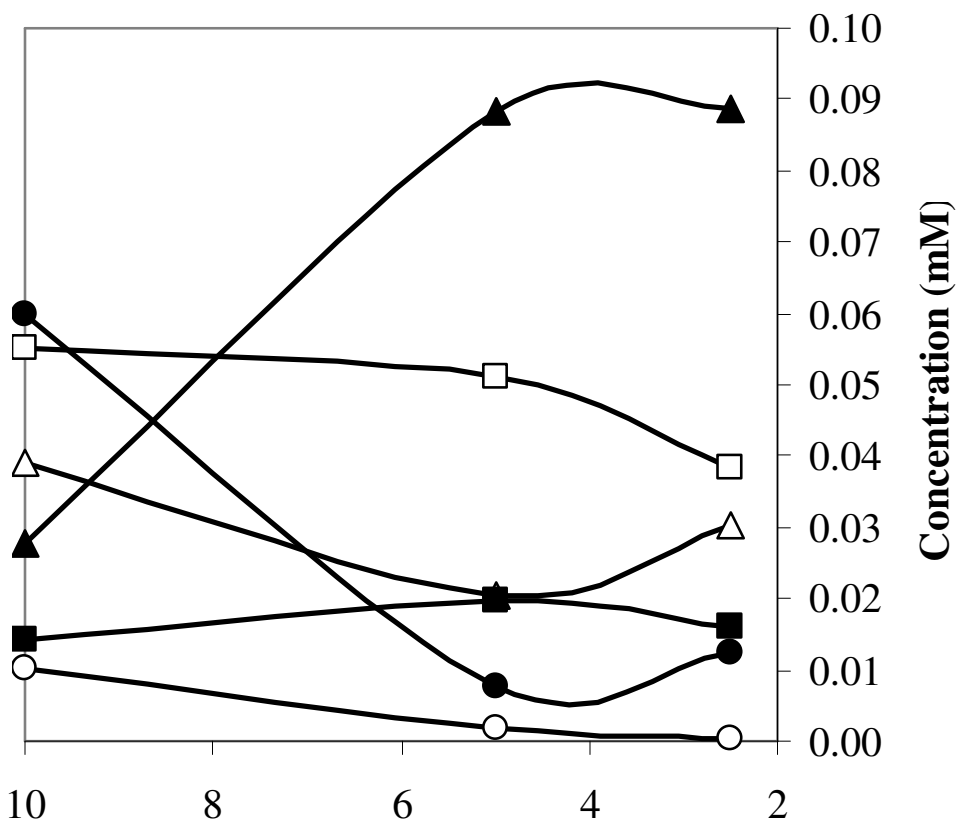

Flow Rate (mL/min)

Figure S9: Concentration of Orange II and its electrolysis products in $0.1 \mathrm{M} \mathrm{KCl}$ using the flow-through packed bed reactor in Configuration CA with current $25 \mathrm{~mA}$ and various flow rates. $\bullet$ - Orange II gap; $\bigcirc$ - Orange II outlet; $\boldsymbol{\Delta}$ - Sulfanilic acid gap; $\Delta$ Sulfanilic acid outlet; $\mathbf{\square}$ - 1,2-naphthoquinone gap; $\square$ - 1,2-naphthoquinone outlet. 


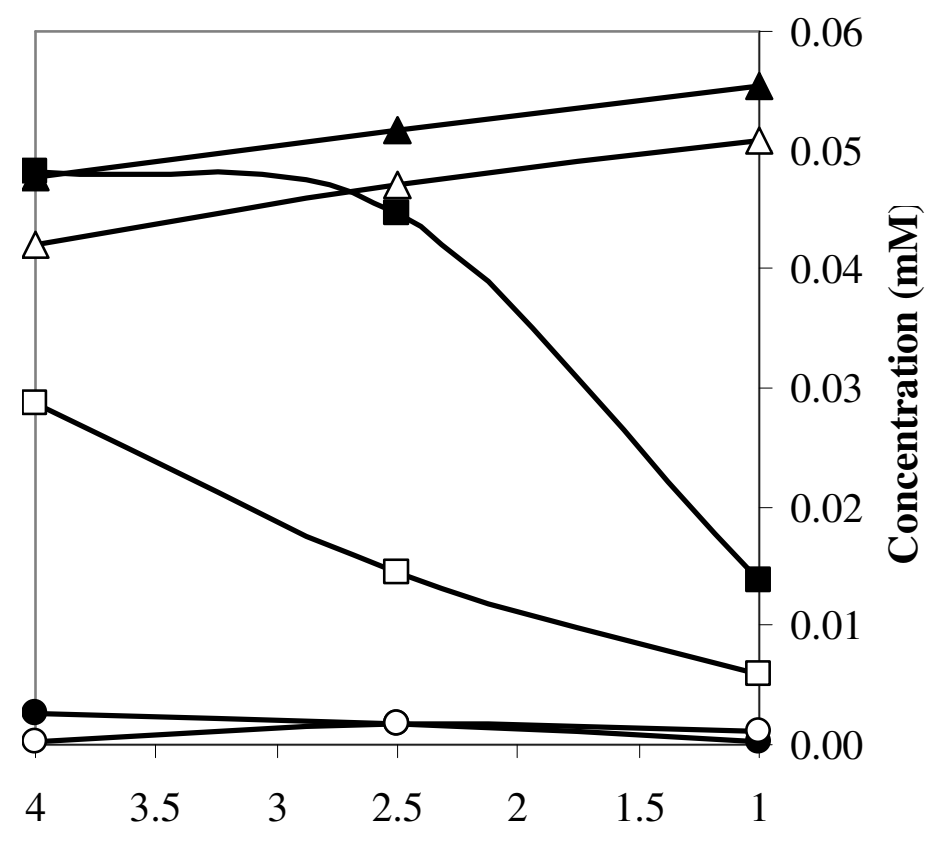

Flow Rate (mL/min)

Figure S10: Concentration of Orange II and its electrolysis products in $0.06 \mathrm{M} \mathrm{Na}_{2} \mathrm{SO}_{4}$ using the flow-through packed bed reactor in Configuration AC with current $200 \mathrm{~mA}$ and various flow rates. - - Orange II gap; $\bigcirc$ - Orange II outlet; $\boldsymbol{\Delta}$ - Sulfanilic acid gap; $\Delta$ Sulfanilic acid outlet; $\mathbf{\square}$ - 1,2-naphthoquinone gap; $\square$ - 1,2-naphthoquinone outlet. 


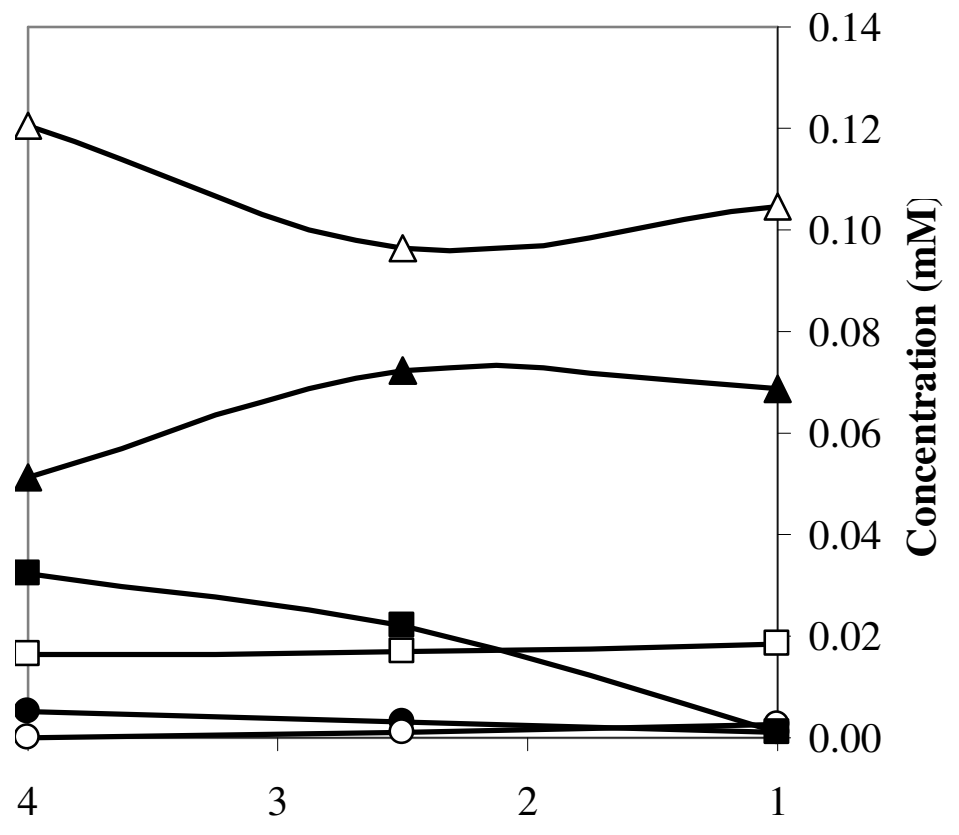

Flow Rate (mL/min)

Figure S11: Concentration of Orange II and its electrolysis products in $0.06 \mathrm{M} \mathrm{Na}_{2} \mathrm{SO}_{4}$ using the flow-through packed bed reactor in Configuration CA with current $200 \mathrm{~mA}$ and various flow rates. - - Orange II gap; $\bigcirc$ - Orange II outlet; $\boldsymbol{\Delta}$ - Sulfanilic acid gap; $\Delta$ Sulfanilic acid outlet; $\mathbf{\square}$ - 1,2-naphthoquinone gap; $\square$ - 1,2-naphthoquinone outlet. 


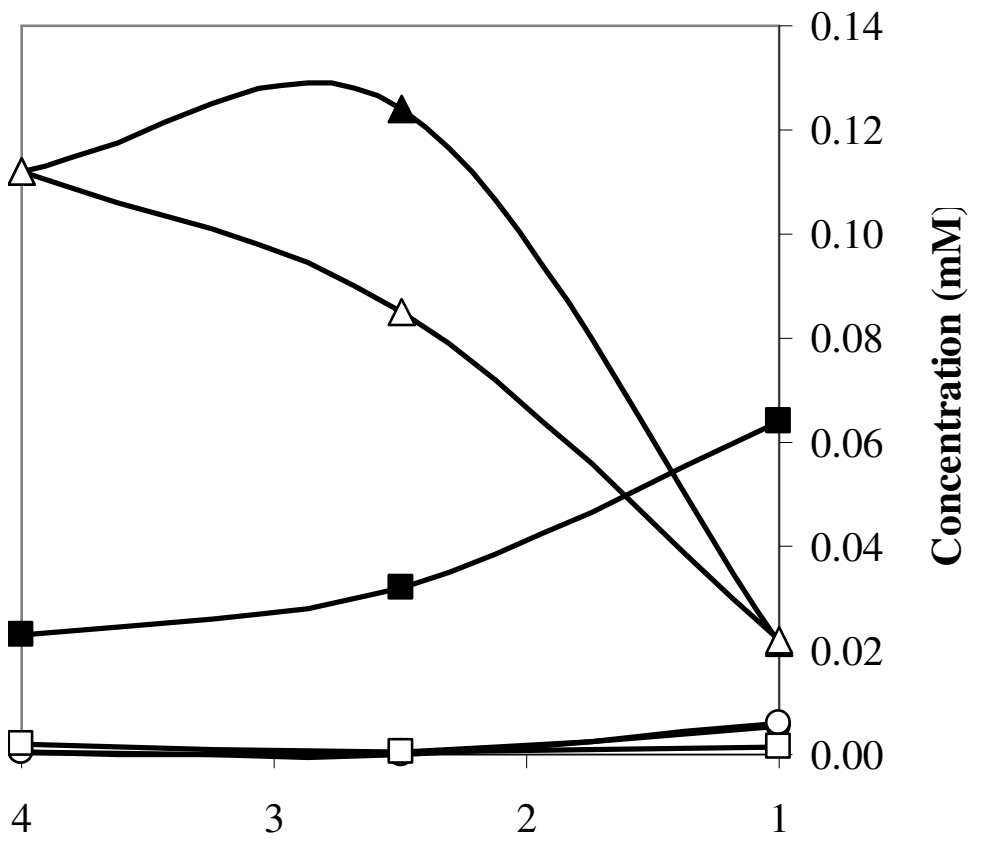

Flow Rate (mL/min)

Figure S12: Concentration of Orange II and its electrolysis products in $0.1 \mathrm{M} \mathrm{KCl} \mathrm{using}$ the flow-through packed bed reactor in Configuration CA with current $200 \mathrm{~mA}$ and various flow rates. - - Orange II gap; $\bigcirc$ - Orange II outlet; $\boldsymbol{\Delta}$ - Sulfanilic acid gap; $\Delta$ Sulfanilic acid outlet; $\mathbf{\square}$ - 1,2-naphthoquinone gap; $\square$ - 1,2-naphthoquinone outlet. 